\title{
The Foresters' New Habitat - Politics - Policies - People "Forestry Gospels"1
}

\author{
H. K. Williams ${ }^{2}$
}

I have noticed over the years that people often turn to the bible for a quotation or a source of ideas. We are unique in the forestry business in B.C. - We have our own gospels that everyone is quoting these days.

The first is the gospel according to Peter - better known as the Royal Commission Report of 1976. This report spelled out - if you'll pardon the pun - Peter's principles for managing and administering the forests of B.C.

The second edition was the three gospels written by Robert Wood of FPAC, and his disciples - better known as The Forest Act, Ministry of Forests Act, and The Range Act.

The third is the Thompson Report. You may ask why do I place the Thompson Report among my list of forestry gospels for B.C.? Well it meets the criteria of being widely quoted, and it is truly unique. In fact, when historians look back on the decades of the '70's and '80's, they will see this is probably the only report on which the minister of forests, the forest service, and a large segment of the forest industry are in agreement.

They all agree that they don't agree with some of the facts in the report. I hope the Minister of Forests' invitation to ridve all parties sit down and determine which figures are correct will be taken up. When a conflict like this arises over a simple matter of statistical records, and is not resolved, a great disservice is done to the forest community at large, including our profession.

Speakers on forestry subjects of late, including the minister of forests, the CEO of my company, and others, have quoted extensively from one or all of these "Forestry Gospels".

Why should I be different? I decided to go to these gospels for references on the topic of our panel - "the foresters new habitat - politics - policies - people'"

I was stunned - the "Gospel" writers of our day - men I know personally - all professional foresters no less had ignored the significance of politicians and people.

As I reflected on this dastardly oversight I wondered were these foresters perhaps fighting back? Did they fail to mention politicians because politicians had for the most part ignored them for decades? They had paid little attention to the foresters plea for more funds, more staff, and better policies to ensure the vast forest wealth of our province is sustained - a wealth whose direct and indirect revenues and employment base had made the politician look good for so many years - irrespective of political stripe.

Did these gospel writers ignore the mention of people because most of the public shows little interest in what goes on in the woods? Oh, the forester hears from a few vocal groups, but when you look under their interest mantle you very often find a skin of self interest. They don't want their backyard logged - they agree we need logging for employment and producion of goods - but go log someone else's backyard, or don't log near their fishing stream - go log someone else's, and so on.

\footnotetext{
1 Paper presented by H. K. Williams, R.P.F., at the annual meeting of the association of British Columbia professional foresters at Vernon, B.C., February 22, 1980.
}

${ }^{2}$ MacMillan Bloedel Limited, 1075 West Georgia Street, Vancouver, B.C. V6E 3R9
The forester's habitat during most of the '70's has been engulfed in a cloud of frustration and uncertainty. He's been frustrated by the intrusion of other resource "experts" into his field of forest management. Not by the true professional expert who has given sound, well-reasoned advice on management of other resources of the forests, but by the so-called "expert" whose input lacks factual support and is highly motivated by emotion or self interest.

He's frustrated by the lengthy delays in policy making forest policy review in British Columbia started seriously in 1974 with the task force on Crown timber disposal, then moved in 1975 to the Royal Commission; the end result, a new forest act, was not proclaimed until January 1, 1979, at least five years in getting the final product and developing the major policies and regulations is going to take at least to the end of 1980 . The foresters, both industry and government, have known frustration through these years of uncertainty.

It has taken a joint government-industry committee over five years to develop new log grades for the coast that better represent the pattern of log end use. These new grades are needed badly by the log marketing agencies and for stumpage valuation. The committee reached a consensus on the new grades over a year ago. How much longer will we wait before they are seriously tested so that they can become official?

I'm beginning to feel that any important decision in the forestry sector requires a five year gestation period to hatch a result.

The forester has survived these delays and frustrating times, but what is the effect on the public? Many known plant expansion plans were held in limbo for several years awaiting finalization of policy and the new forest act. The same can be said for development of more intensive forestry programs of some companies. How many manyears of work and how many dollars of revenue have been forgone in these instances while awaiting policy decisions?

Looking forward to the ' 80 's the cloud of frustration and uncertainty is lifting. Somehow, somebody has hit some sensitive nerves in the legislatures of Ottawa and Victoria, and in the corporate boardrooms, and a new era is dawning for forest management.

Mr. Bennett (Premier of B.C.) has announced government policy with more emphasis on forest management, John Fraser (Federal Minister of Environment) is calling for an expanded CFS and increased expenditure by both senior levels of government on forest management. Calvert Knudsen (CEO of $\mathrm{MB}$ ) recently publicly announced an expanded intensive forestry program called the designed forest system costing in the order of $\$ 15$ million annually (plus inflation in future years). Four companies are currently negotiating with the ministry of forests for establishment of industrial forest nurseries. Our new habitat looks exciting, and challenging. Are we as foresters ready for the challenge?

I would like to conclude by coming closer to home, and talk about our association. The habitat for recent councils has also been one of frustration. We have an act and a statement of policy, the latter by the way is ten years old. It may be time to see if our policy statement meets the needs of the 
challenging ' 80 's. Councils have a set of objectives which they have been ill-equipped to meet, particularly the last two: i.e.

- To promote policies of integrated use of forest land for the greatest social and economic returns to society, and

- To advise the public and governments of the implications of policies affecting uses of forest land.

Successive councils have tried to get the tools to meet objectives two and three, but are repeatedly turned down by the membership - not by a majority of the membership but by a minority (they need a $2 / 3$ majority to pass a resolution).

If my company gives me an objective that I am not equipped to meet, I ask my boss to remove the objective or give me the tools to do the job. I don't like the consequences of not meeting an objective.

We are entering a new era in forest management in British Columbia. If we foresters neglect to fulfil all the objectives of our professional association, I think the consequences will not be to our liking. We can credit the Jack Munros, the Les Reeds, and some of the special interest and environmental groups, for a tremendous assist in getting forest management the attention it deserves. There is strong evidence that the politicians and industrial senior management are reacting as we would like.
It is the role of the professional forester to keep the forest management bandwagon on the road and don't think there won't be forces trying to move it off.

We have the expertise, thanks to the fact we have at least met our first objective reasonably well. Although we must never cease to strive to improve the profession in both quality and quantity. Les Reed has said "foresters are a retiring lot, most of them just wring their hands and mutter how dreadful things are, and hardly any of them are interested in policy". Is he right? I hope not!

The time has come to make up our minds about our last two objectives. I urge the incoming council to ask the membership once again for the means to achieve them. If it's again the decision of the membership to say no - then you have no alternative but to remove objectives two and three from our policy statement - you are compromising our professional ethics to do otherwise.

Oliver Wendell Holmes, the great American jurist, once said:

"A man should be part of the action and passion of his times." Foresters must assume an increased share of the burden in shaping the central policy lines in B.C.'s major industry. Only then will we definitely be part of the main "action and passion" of our times.

\section{The Forester's New Habitat - The Social and Political Niche}

\section{Ron Arnold1}

I am sure one could not find a subject that needs to be understood more than "The Forester's New Habitat: People, Politics and Policies," or one that is more frustrating. It took a special kind of bravery to face this new habitat squarely - some might say a special kind of masochism.

I have a suspicion that the increasing activism of environmentalists in Canada may have had a little something to do with the choice of this year's theme. Thus I decided to preface my remarks with a funny story about environmental activism - but I couldn't think of one.

So we'll just have to skip the humor this morning, which is something I find more and more professional foresters doing in their daily lives these days. There's nothing terribly funny about being assaulted by a public that is not as well informed as it might be. I've seen some of the good nature and springly step that I have come to associate with foresters begin to fade in the past few years. A cloud of concern and bewilderment seems to have drifted into the woods, brought in on the rising tide of public interest in the forest environment.

I don't think you need a great deal of reminding about what the public has been doing in the woods lately, so I am going to deal with the question of why they have been doing

\footnotetext{
1 Ron Arnold is a communication consultant in Bellevue, Washington, U.S.A. He has serv ed with the Sierra Club and Alpine Lakes Protection Society (ALPS). Based upon his ex perience he became a critic of the environmental movement's methods and motives.
}

it. In other words, I'll explore a particular niche of the forester's new habitat: the social and political niche those larger forces that have resulted in the specific impacts of the public on your lives.

The social and political niche of the forester's habitat used to be relatively barren and empty, occupied occasionally by transient organisms on holiday from their urban habitat, and perhaps by a few regular denizens of the bureaucracy and maybe a member of parliament now and then. But there has been a population explosion in the social and political niche in the past ten years, and the change in quantity of its occupants has been accompanied by a change in their quality. The new population seems to be more sensitive to recreational and aesthetic matters. It appears to have lost some of Canada's old pragmatism and adopted a new and strange ideological stance. In place of asking how we should increase productivity, they seem to be asking "should we increase productivity?" And a lot of other questions that we had not heard before, or heard only faintly from a few voices crying in the wilderness.

How can we make sense of these changes? In asking myself this question over the last decade I have concluded that we can only understand the changes in the forest if we understand the changes in the larger society. There have been a number of important scholarly studies done on the social changes in North America since World War II, but the one most illuminating for our purposes was done by a political scientist at the University of Michigan, a man named 